\title{
Role of habitat variability in trout population dynamics: Application of a dynamic population model to three French rivers
}

\author{
V. Gouraud ${ }^{(1)}$, C. Sabaton ${ }^{(1)}$, H. Capra ${ }^{(2)}$ \\ Corresponding Author: Veronique Gouraud, veronique.gouraud@edf.fr
}

\begin{abstract}
The Instream Flow Incremental Methodology (IFIM) was developed to determine flows that must be maintained downstream of hydropower plants to preserve aquatic populations. It is based on the hypothesis that the characteristics of the habitat in periods of low flow have a crucial impact on the dynamics of these populations. Other parameters that may also affect populations include: water quality, temperature, flood episodes, strategies for stocking, fishing, etc. Dynamic models of fish populations are now being developed in an attempt to integrate all these factors. The model presented here was applied on 3 populations (on Oir River, Neste d'Oueil River, and Roizonne River). The study has highlighted the fundamental role of the temporal variability of environmental parameters (particularly temperature, discharge and Weighted Surface Area) in structuring trout populations. Particularly, the flow-related habitat role simulated in the model - through a phenomenon of compensation during the first months of life and through displacement resulting in mortality, and mortality among fry when discharge is high - was illustrated by these examples.
\end{abstract}

Key words. - population dynamics, modeling, Leslie matrix, IFIM, brown trout

\section{INTRODUCTION}

The objective of achieving an improved balance between preserving the ecological integrity of hydrosystems and the diverse uses of water has been clearly reaffirmed in the 2000 European Water Framework Directive (EWFD, 2000/60/CE, JO L327
$-22 / 12 / 00)$. Above and beyond mere words, it opens up a vast field of applied research to develop reliable, validated tools to diagnose the real ecological status of water bodies (Pollard \& Huxham, 1998) and to predict their future trends (Sabaton, 2002; Souchon et al., 2002; Souchon \& Keith, 2002). In the last fifteen years, choosing the minimum instream flow

(1) Electricité de France, Division Recherche et Développement, Departement LNHE - 6, quai Watier 78400 Chatou, France.

(2) Cemagref, U. R. Biologie des Ecosystèmes Aquatiques, Laboratoire d'Hydroécologie Quantitative, 3 bis quai Chauveau, CP220, 69336 Lyon Cedex 09, France. 
to be maintained downstream of hydropower plants is a good example of the kind of problem that must be solved. The IFIM "microhabitat" method is one of the only approaches which allows coupling hydraulic data and biological data (e.g. habitat preference) to simulate change in the potentially available habitat (that quantified by "Weighted Surface Area" - WUA-) for an aquatic species as a function of discharge (Nehring \& Anderson, 1993). Nonetheless, despite its widespread use throughout the world, the microhabitat method has not yet been satisfactorily validated in biological terms (Lamouroux et al., 1999; Kondolf et al., 2000). In this context, and to investigate the impact of a modification in the environment on the dynamics of the populations in place, models which couple the internal dynamics of a fish population and its possible response to changing habitat conditions are now being developed (Cheslak \& Jacobson 1990; Williamson, Bartholow \& Stalnaker 1993; Jager et al, 1993). In a similar vein, Electricite De France (EDF) has developed a structural biological model coupled with a physical model that estimates habitat conditions for the different age classes of the brown trout -Salmo trutta L(Sabaton et al, 1998).

This population dynamics model (MODYPOP) has been applied to three populations of trout which are extremely different in terms of their biological characteristics as well as the habitats in which they live. MODYPOP was first applied to the
Oir, a river in lower Normandy (Gouraud et al, 1998) where restoration of the population following a sudden decline due to a sharp rise in temperature was simulated. It was next applied to the Neste d'Oueil in the Pyrenees (Gouraud et al., 2001), where regulation of the population through carrying capacity constraints in low-water periods was represented. Lastly, MODYPOP was applied to the Roizonne, in the Alps (Capra et al., 2003), where strong spring flooding appears to have a significant impact on the dynamics of the trout population in place.

These applications have enabled comparing the dynamics of the three populations and identifying the factors that regulate their numbers in different environmental contexts (geographical location, type of aquatic habitat, etc.).

Two rivers - the Oir and its affluents in Lower Normandy and the Neste d'Oueil in the Pyrenees - and the upstream reach of the Roizonne in the Alps are all characterized by natural fluctuations in discharge. The input parameters for the model are the values for the biological functions specific to each of the three populations and the physical characteristics of the three environments (discharge and rating of habitat quality, temperatures).

In this paper, the simulated variations in trout abundance are compared with those actually observed during the years for which monitoring data are available at the three sites. 
MATERIAL AND METHODS

\section{Description of the model}

\section{Principle}

The MODYPOP model has already been presented in detail by Sabaton et al. (1998). Only the essential features are given here (Figure 1).
This model, based on the Leslie matrix (Leslie, 1945), simulates change in a trout population using biological parameters which are dependent on environmental conditions. The population is broken down into age classes, and the numbers in each age class are calculated over time (Figure 1). A one-month time step is chosen to take into account cli-

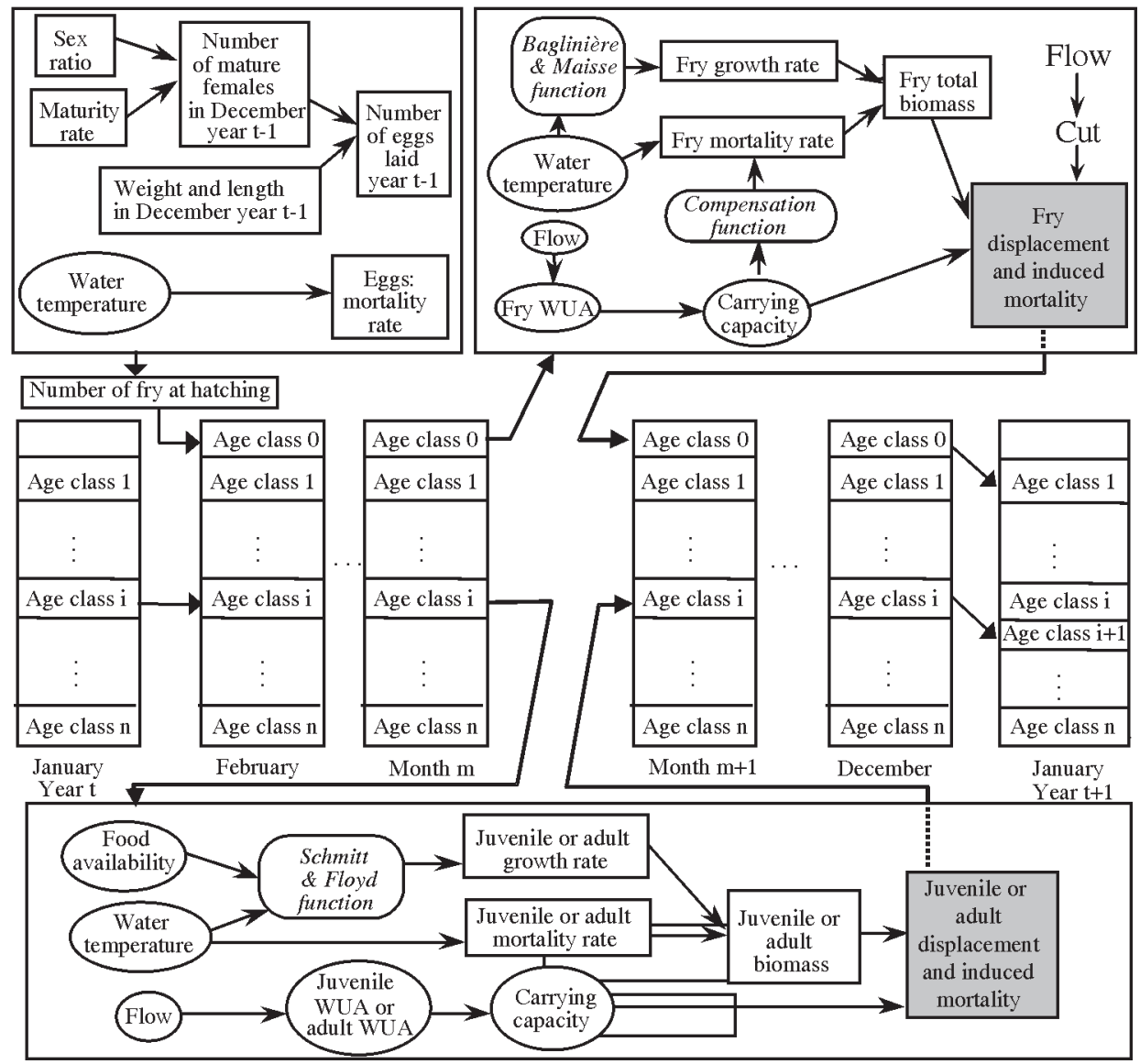

Fig. 1. - General schematic diagram of MODYPOP (trout population dynamics model), from Sabaton et al. (1998). All different stages are presented with the shaded components being directly influenced by habitat 
matic variations and their impact on the population. Numbers in a given age class vary in accordance with monthly survival and growth rates and with displacement related to fluctuation in the habitat (using WUA time series). At the end of the year, survivors move into the next age class. In the month in which eggs hatch (generally February in France), the $0+$ class is supplied by the eggs laid by mature females at the end of the year (generally December in France). The demographic parameters (survival, fertility, growth rates, displacement) are dependent on temperature, trophic availability in the environment and carrying capacity (Bovee, 1982); the coefficients for these functions are calibrated for each population studied so as to integrate knowledge acquired regarding the biological characteristics of the population and the environment being studied. Mean survival for the first age class corresponds to that calculated using Leslie's annual model for a balanced population (Leslie, 1945).

\section{Regulation owing to habitat conditions}

The population is regulated by two types of mechanisms linked to habitat availability:

- an increase in the survival rate in the first months of life, to represent the capacity of the population to return to a size compatible with the habitat potential when the river is under-occupied. This potential the potential biomass of the river - is often expressed on the basis of the adult biomass in $\mathrm{g} \mathrm{m-2}$ of WUA in low-flow periods (Bovee, 1982; Souchon et al., 1989; Cheslak and Jacobson, 1990; Williamson et al., 1993) and in France, it varies from around 30 to $65 \mathrm{~g} \mathrm{~m}-2$ (Souchon et al., 1989; Baran, 1995).

- adjustment of the population to the local carrying capacity, represented by displacement leading to mortality in cases of over-density.

On a more local and more instantaneous scale than that described above, the carrying capacity at one given moment is defined as the maximum biomass that can be supported in a particular river reach for a given WUA value. It will be estimated using the maximum occupancy rates observed (biomass/WUA) during fishing inventories. We then assume that the trout move from place to place in accordance with fluctuations in the monthly WUA and in particular, when habitat conditions become temporarily limiting in relation to the biomass present, which is to say when the biomass exceeds the maximum occupancy rate. This displacement is assumed to result in partial mortality, depending on the age of the fish.

Corrective factors related to temperature

From the time of emergence, mortality is increased in the event of high temperatures. The corrective factor linked to thermal impact varies from 1 to 0 ; it is a multiplicative factor of mean survival and tends to increase 
mortality during particularly hot months. The survival rate is considered to decrease above $19^{\circ} \mathrm{C}$ for fry (decline in the thermal preference curves given by Bovee, 1978), reaching $0 \%$ at a lethal temperature of around $26^{\circ} \mathrm{C}$ (nil thermal preference, according to Bovee); for older individuals, the survival rate declines as the temperature rises from $20^{\circ} \mathrm{C}$ to $29^{\circ} \mathrm{C}$ (thresholds determined on the basis of thermal preference curves given by Bovee, 1978).

These corrective factors can be calculated using a time step of less than one month, if daily data are available, in order to allow for high temperatures lasting only a matter of days. Such temperatures are detrimental to fish, but the incident might pass unnoticed if only mean monthly temperature is used.

\section{Corrective factors related to floods}

The impact of flooding, simulated in the model by diminished WUA linked to the strong discharge, is poorly represented in that the phenomenon of entrainment of young due to the high velocity is not clear (Gouraud, 1999). Other studies (Nehring and Anderson, 1993; Latterell et al., 1998; Cattanéo et al., 2002) show that the most critical life phase in these hydrological episodes is the post-emergence phase, during which there seems to be a dramatic decrease in the numbers of young of the year, though neither threshold discharge values nor minimum duration of strong discharge are specified.
One study of three other trout populations in natural French rivers (Capra, 1998) suggests that the decrease in the number of $0+$ is relatively great when the sum of the Continuous Under Threshold (CUT) curves (Capra et al., 1995) between March and May (the limiting discharge threshold being set at mean annual discharge +2 standard deviations) is at least equal to 5 days. Additional mortality at the end of the post-emergence period (end of May) has therefore been increased for the $0+$ individuals having experienced such episodes. One such discharge threshold value was tested. To calibrate this mortality level, simulations were run for additional mortality rates of $0 \%, 50 \%$ and $75 \%$.

\section{Application sites}

The model was applied to three sites in France: in the Oir basin, where the populations have been studied since 1988, on the Neste d'Oueil in the Pyrenees where the population was monitored for 3 years by means of three inventories per year, and on the Roizonne where the population has been monitored since 1990.

\section{Study sites}

The Oir is a tributary on the right bank of the downstream reach of the Sélune, a small coastal river in Lower Normandy (Figure 2) which forms an estuary in the bay of Mont SaintMichel. Its source is at an altitude of 


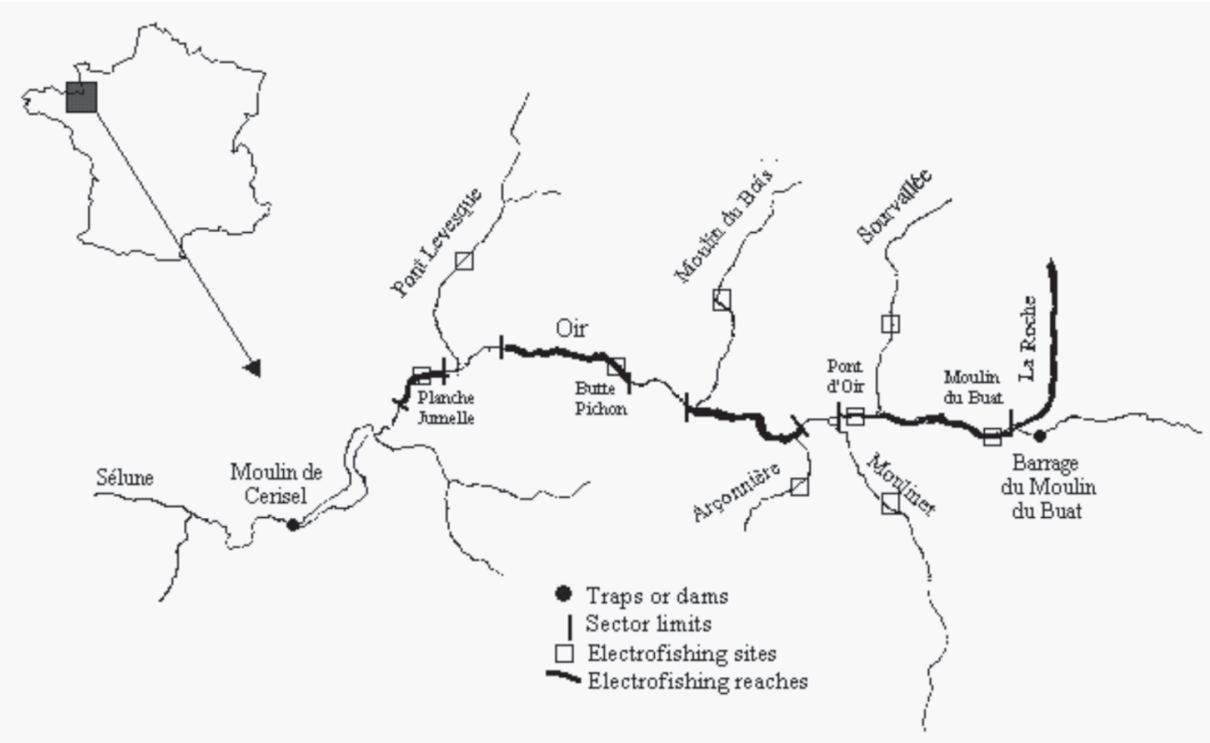

Fig. 2. - Geographical location of the Oir site

$225 \mathrm{~m}$; it flows east to west over a distance of $19.5 \mathrm{~km}$ with a mean slope of $11 \%$, and has approximatively ten tributaries. A monitoring migration site (up- and downstream) is set up at Moulin de Cerisel, $2.5 \mathrm{~km}$ upstream of the point where the Oir joins the Sélune. Trout colonize the entire watershed, but the Moulin du Buat dam, located on the Oir $14 \mathrm{~km}$ from the confluence with the Sélune, constitutes a very difficult obstacle. The model was therefore applied to the section of the Oir and its six affluents between the dam and the monitoring site. This zone can be considered to be a closed, or at least controllable system. The hydrological regime is of the pluvial type with one low-water period from July to September and high water during January and February.
The Neste d'Oueil is a sub-tributary of the Garonne watershed in the Pyrenees (Figure 3). It is formed at an altitude of $1,450 \mathrm{~m}$ by the confluence of several streams whose sources are at $1,850 \mathrm{~m}$. It joins with the One at an altitude of $765 \mathrm{~m}, 9.2 \mathrm{kms}$ further on. Its mean slope is $11.8 \%$ and the width varies from 4 to $6 \mathrm{~m}$. The hydrological regime is of the pluvio-nival type with two low-water periods (winter and summer), and high water levels during the spring melt.

The Roizonne is formed at an altitude of $1100 \mathrm{~m}$ by the confluence of the Vaunoire (a torrent flowing from the Taillefer massif in the southwest Alps) and the Lava, and joins the Bonne (Rhône watershed) $15 \mathrm{~km}$ further downstream at Pont Haut (583 $\mathrm{m}$. in altitude). Its mean slope is 


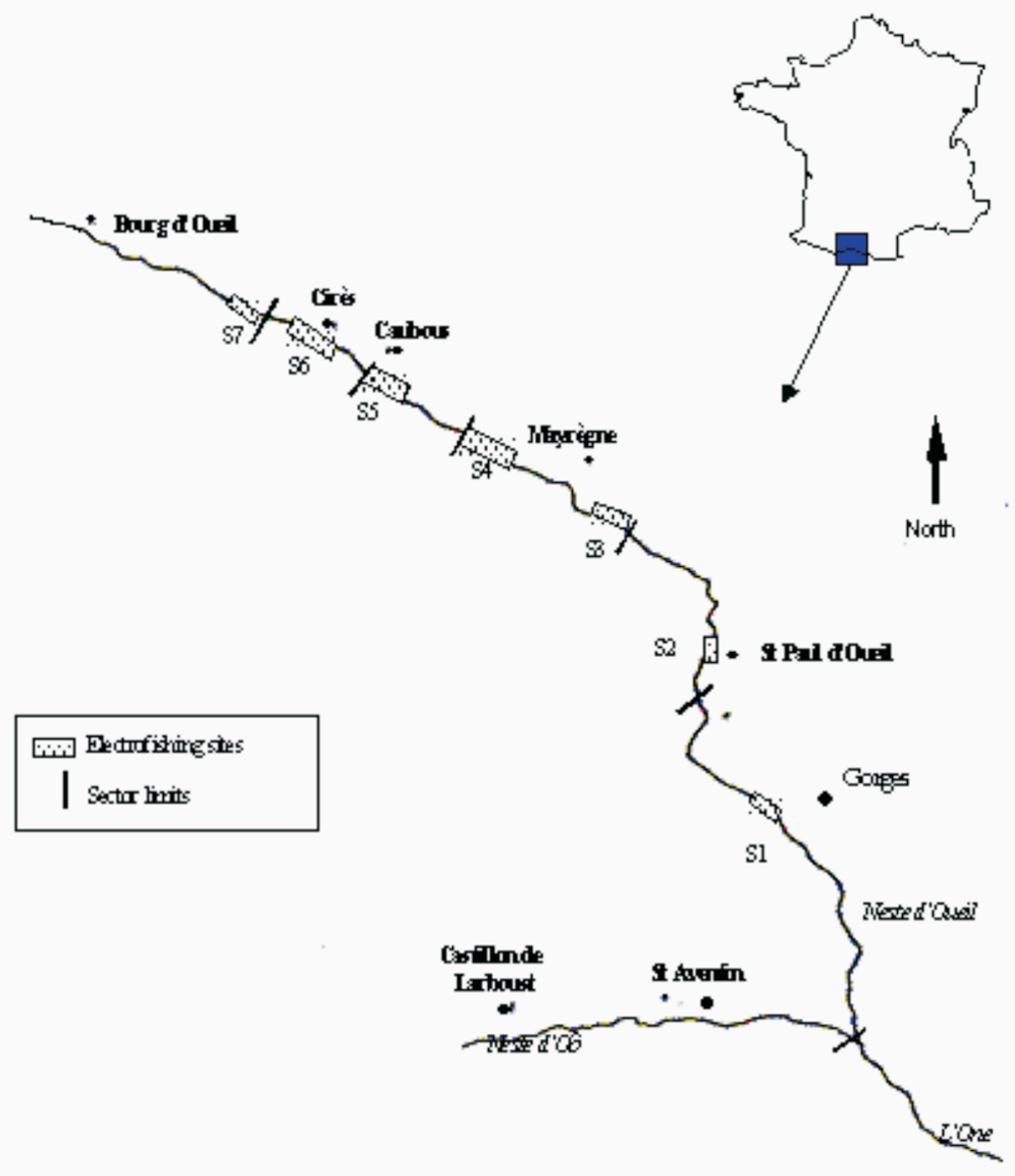

Fig. 3. - Geographical location of the Neste d'Oueil site

3 to $4 \%$ and its mean width, $6 \mathrm{~m}$. The hydrological regime is pluvio-nival with strong flooding at the time of the spring melt, in April and May. A reservoir created at km. 12.1, allows for diversion of a maximum of $4.4 \mathrm{~m}^{3} \mathrm{~s}^{-1}$ to supply a hydropower plant located at Pont Haut (Figure 4).

\section{Trout populations}

The populations were monitored at the three study sites to estimate density per age class present in all zones studied as well as their growth rates and reproductive potential (Gouraud, 1999; Capra et al., 2003). 


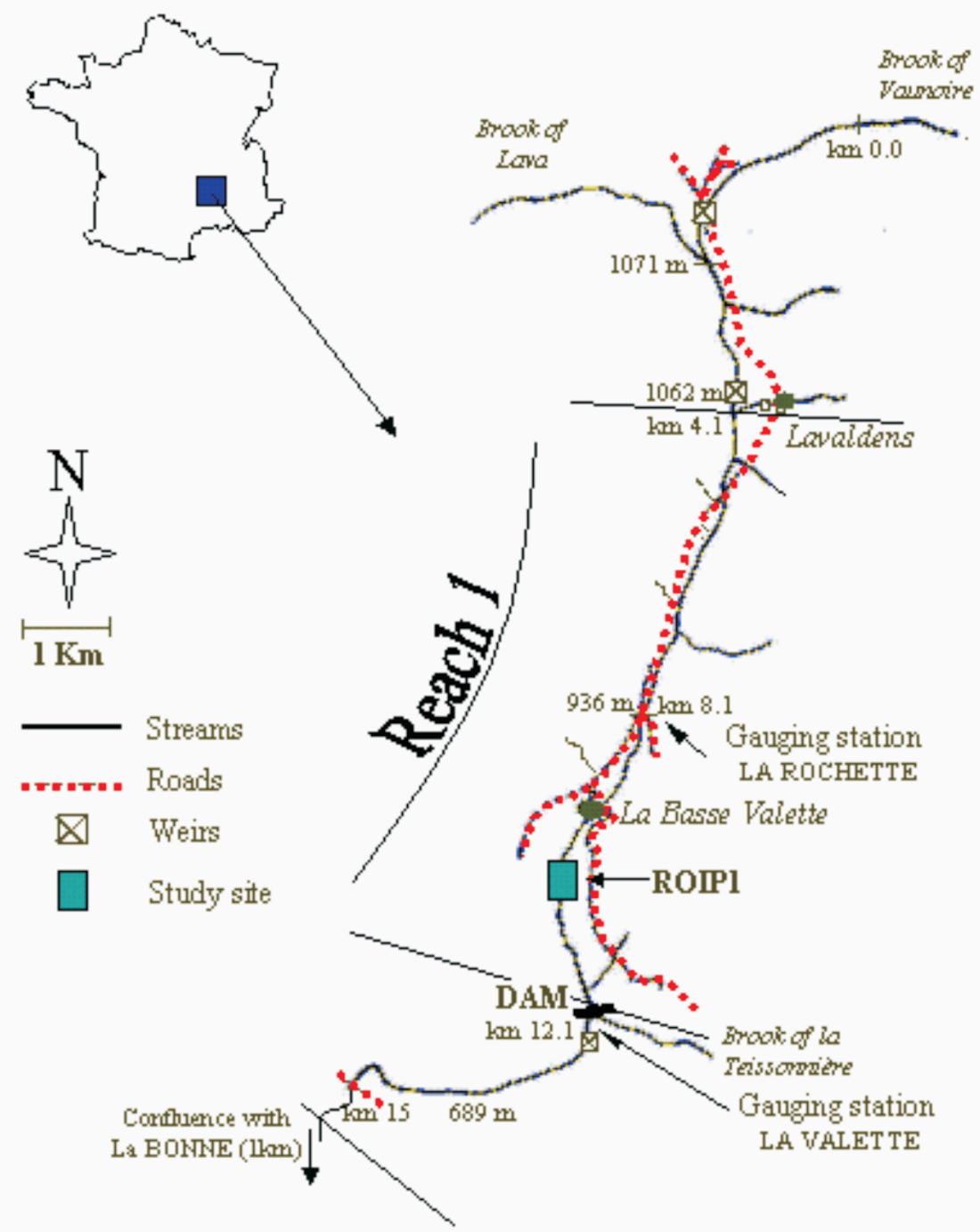

Fig. 4. - Map of the river Roizonne. Study reaches ( 1 = natural section; 2 = bypassed section) and study sites, cities, gauging stations, weirs, and dam location are indicated.

The Oir watershed. Since 1988 (with the exception of 1990), electrofishing inventories have been carried out in May and October on the
La Roche stream, and in October on the Oir. On the affluent, the inventory covers almost the entire reach, a distance of around $2 \mathrm{~km}$. On the Oir, the 
trout population was inventoried at 4 sites representative of the habitat in the complete stretch studied. However, from 1996 to 1998, the inventory was extended to between 47.9 and $70.3 \%$ of the full stretch and to several sites representative of five other affluents in the area studied. This allowed us to estimate densities of trout in the whole Oir basin. During these surveys, different biometric parameters (size, weight) were measured and samples (scales, gonads) taken, with a view to analyzing demographic characteristics (age structure, relative proportions of both sexes, age of sexual maturity, fecundity of females and potential for reproduction). No accurate data concerning survival rates were available on the Oir river. To apply the model, we used mortality rates estimated in the nearby river "Le Kernec" (Baglinière \& Maisse, 1991).

The Neste d'Oueil. A complete survey of the area allowed us to determine the percentage of different types of mesohabitats (as defined by Delacoste et al., 1995) in the river. On the basis of this morphodynamic survey, seven different reaches were identified. Fish populations were sampled by electrofishing in sites representing each of those reaches in July 1996, September 1996, February 1997 and July 1997 (Figure 3). Before sampling, each mesohabitat was isolated upstream and downstream by block nets (mesh size: $8 \mathrm{~mm}$ ). Fish numbers, as well as fish length $(\mathrm{mm})$ and weight $(\mathrm{g})$, were recorded. Fish densities were estimated for each age class and for each mesohabitat unit. The morphodynamic survey allowed an extrapolation of fish population density to the whole stretch.

Significant inputs of hatchery fry $(0+)$ should be noted. The specific growth of these $0+$ individuals enabled identifying them and estimating their numbers. These inputs and the strong growth rates of these individuals are simulated in the model. Complementary inventories were performed beginning in February 1998 on some affluents which, due to their high slope, were thought to be not very productive, in order to simulate the possible arrival of some individuals in the main river.

The Roizonne. The study concerned one $8-\mathrm{km}$ reach upstream of the reservoir (Figure 4). The morphology of this reach consists essentially of rapids. The other morphological units, with slower flow, have been assimilated to pools. One representative study site was selected in the reach (ROIP1). Fish inventories were carried out, isolating the trout according to the type of morphological unit (rapids and pools). The total population in the reach represented by the site was estimated with the ratios of the proportions of each type of morphological unit at the site and in the reach.

The trout population was inventoried by means of electrofishing in October 1990 and 1994, in December 1999, and in September 2000 at the ROIP1 site. 
All the fish caught were identified, measured (total length in $\mathrm{mm}$ ) and weighed (in g).

\section{Habitat study}

In the three watersheds, water velocities, depths and substrate were measured in characteristic sites. Curves were thus established for variation in WUA according to discharge. WUA chronologies were reconstituted using available records of discharge from 1988 to 1998 for the Oir basin, from July 1996 to March 1999 for the Neste d'Oueil and from 1990 to 2000 for the Roizonne.

To study the influence of floods on the Roizonne population, the discharge time series were analyzed by means of the CUT curve method (Capra et al., 1995). This made it possible to inventory the continuous duration (in days), during the study periods, during which the discharge exceeded a threshold judged to be critical.

The strong discharge from March to May was defined in relation to the disturbance threshold proposed by Resh et al. (1988), i.e. mean annual discharge +2 standard deviations. We calculated the value of this threshold with the natural discharge time series.

\section{Application of the model}

Oir. Monitoring of the populations (fecundity, growth, etc.) and knowledge of the habitat conditions made it possible to apply the model to the Oir basin for a period of several years. A first simulation covered the period from 1988 to 1998 and used temperatures based on a one-month time step (Gouraud et al., 1998). With this time step, it was not possible to simulate the effect on the individuals of the high summer temperatures in 1991 and 1997 (monthly means below $19^{\circ} \mathrm{C}$, although 28 and 15 days respectively had mean water temperatures higher than this), which clearly affected the population. The simulations presented here for the Oir basin were therefore run, calculating the corrective coefficients for survival using a daily time step.

Neste d'Oueil. In order to study more specifically any mechanisms by which habitat conditions limit the population, the model was applied to the Neste d'Oueil from mid-1996 to mid1999 , examining respectively the simultaneous monthly changes in adult biomass and carrying capacity for adults.

Roizonne. The simulations were run testing the three post-emergence mortality rates during floods $(0,50$ and $75 \%$ ) for the threshold equal to mean annual discharge +2 standard deviations. The simulation concerned the reach upstream of the reservoir.

The results of the simulations were then compared with the estimations of trout numbers and biomasses present at the time of the inventories in order to see if the trends in change simulated using the two regulating phenomena were realistic. 


\section{RESULTS}

\section{Trout populations}

On the Oir, there is significant migration of breeder adults upstream near the affluents, while on the Neste d'Oueil and on the Roizonne, migration of these same adults is far more limited in space and takes place essentially in the main river, as inventories in spawning grounds have shown. The three trout populations studied are quite different. Those in the Oir are characterized by rapid growth, relatively early sexual maturity and a rather short life span. Those in the Neste d'Oueil, on the other hand, have slow growth rates, later sexual maturity and a longer life span. Lastly, the Roizonne population is characterized by growth, fertility and life cycle values that are more or less a mean in relation to the other two populations. The principal biological characteristics are shown in Table 1.

Estimations of numbers and biomass on the basis of the different inventories also show significant differences with respect to change in the populations over time. While the Oir population continues to increase over almost the entire period of the study, and those in different sectors of the Neste d'Oueil are relatively stable from one year to the next, the Roizonne stocks vary widely over the monitoring period (Table 2).

Table I. - Demographic parameters of the Oir, Neste d'Oueil, Roizonne populations

\begin{tabular}{|c|c|c|c|c|c|c|}
\hline & \multicolumn{2}{|r|}{ Oir watershed } & \multicolumn{2}{|r|}{ Neste d'Oueil } & \multicolumn{2}{|r|}{ Roizonne } \\
\hline Number of age classes & & 5 & & 7 & & 5 \\
\hline \multirow[t]{7}{*}{ Survival rate } & $0+$ & $5 \%$ * & $0+$ & $7 \%$ \%* & $0+$ & $4 \% \%^{* *}$ \\
\hline & $1+$ & $40 \%$ * & $1+$ & $45 \%$ & $1+$ & $50 \%$ \\
\hline & $2+$ & $40 \%$ * & $2+$ & $45 \%$ & $2+$ & $40 \%$ \\
\hline & $3+$ & $40 \%$ * & $3+$ & $35 \%$ & $3+$ & $40 \%$ \\
\hline & $4+$ & $0 \%$ * & $4+$ & $35 \%$ & $4+$ & $0 \%$ \\
\hline & & & $5+$ & $35 \%$ & & \\
\hline & & & $6+$ & $0 \%$ & & \\
\hline \multirow[t]{4}{*}{ Mean size } & $0+$ & from 84 to $88 \mathrm{~mm}$ & $0+$ & from 61 to $82 \mathrm{~mm}$ & $0+$ & $69 \mathrm{~mm}$ \\
\hline & $1+$ & from 170 to $196 \mathrm{~mm}$ & $1+$ & from 100 to $122 \mathrm{~mm}$ & $1+$ & $132 \mathrm{~mm}$ \\
\hline & $2+$ & from 220 to $256 \mathrm{~mm}$ & $2+$ & from 137 to $163 \mathrm{~mm}$ & $2+$ & $183 \mathrm{~mm}$ \\
\hline & $\geq 3+$ & from 250 to $335 \mathrm{~mm}$ & $\geq 3+$ & from 179 to $274 \mathrm{~mm}$ & $\geq 3+$ & around $247 \mathrm{~mm}$ \\
\hline $\begin{array}{l}\text { Fecundity ( } \% \text { of mature } \\
\text { females and number of } \\
\text { eggs per } \mathrm{kg} \text { ) }\end{array}$ & $\begin{array}{l}1+ \\
\geq 2+\end{array}$ & $\begin{array}{l}12 \% \text { and } \\
3260 \text { eggs/kg } \\
100 \% \text { and } \\
3260 \text { eggs/kg }\end{array}$ & $\begin{array}{l}1+ \\
2+ \\
\geq 3+\end{array}$ & $\begin{array}{l}2 \% \text { and } \\
2150 \text { eggs/kg } \\
30 \% \text { and } \\
2150 \text { eggs/kg } \\
100 \% \text { and } \\
2150 \text { eggs/kg }\end{array}$ & $\begin{array}{l}1+ \\
2+ \\
\geq 3+\end{array}$ & $\begin{array}{l}0 \% \\
100 \% \text { and } \\
2800 \text { eggs/kg } \\
100 \% \text { and } \\
2800 \text { eggs/kg }\end{array}$ \\
\hline
\end{tabular}

\footnotetext{
*: for Kernec river (Bagliniere \& Maisse, 1991), ${ }^{* *}$ : calculated for a balanced population
} 
Table 2. - Mean densities (ind./100 $\mathrm{m}^{2}$ ) of brown trout caught by electrofishing in representative sites: main stream and La Roche tributary for the Oir basin (a) and two sites on the main stream for the Neste d'Oueil (b) from Gouraud et al. (2001) and one site on the main stream for the Roizonne (c)

\begin{tabular}{|c|c|c|c|c|}
\hline $\begin{array}{c}\text { Oir } \\
\text { Basin } \\
\text { (a) }\end{array}$ & \multicolumn{2}{|c|}{$\begin{array}{c}\text { Density in } \\
\text { Oir river }\end{array}$} & \multicolumn{2}{c|}{$\begin{array}{c}\text { Density in } \\
\text { La Roche } \\
\text { tributary }\end{array}$} \\
\hline & $0+$ & $\geq 1+$ & $0+$ & $\geq 1+$ \\
\hline Oct-88 & 12.1 & 2.5 & 24.1 & 3.8 \\
\hline Oct-89 & 3.9 & 0.8 & 38.8 & 4.4 \\
\hline Oct-90 & & & & \\
\hline Oct-91 & 0.4 & 0.5 & 23.8 & 0.8 \\
\hline Oct-92 & 1.1 & 1.2 & 21.8 & 4.8 \\
\hline Oct-93 & 0.6 & 1.4 & 20.6 & 4.8 \\
\hline Oct-94 & 0.5 & 1 & 15.7 & 8.0 \\
\hline Oct-95 & 0.4 & 1.2 & 33.5 & 6.2 \\
\hline Oct-96 & 3.4 & 3.3 & 43.7 & 8.2 \\
\hline Oct-97 & 2.8 & 4.2 & 22.6 & 8.4 \\
\hline Oct-98 & 0.2 & 3.5 & 16.4 & 4.0 \\
\hline
\end{tabular}

\begin{tabular}{|c|c|c|c|c|c|c|c|}
\hline \multirow{2}{*}{$\begin{array}{l}\text { Neste } \\
\text { d'Oueil } \\
\text { (b) }\end{array}$} & \multicolumn{2}{|c|}{$\begin{array}{l}\text { Bourg } \\
\text { d'Oueil }\end{array}$} & \multicolumn{2}{|c|}{ Mayregne } & \multirow{2}{*}{$\begin{array}{l}\text { Roi- } \\
\text { zonne } \\
\text { (c) }\end{array}$} & \multicolumn{2}{|c|}{ ROIP 1} \\
\hline & $0+$ & $\geq 1+$ & $0+$ & $\geq 1+$ & & $0+$ & $\geq 1+$ \\
\hline July-96 & 10.6 & 44.6 & 3.1 & 35.4 & Oct-90 & 4 & 11 \\
\hline Sept-96 & 10.6 & 43.8 & 7.9 & 31.4 & Oct-94 & 8 & 9 \\
\hline Feb-97 & 5.0 & 25.6 & 3.3 & 17.3 & Oct-95 & & \\
\hline July-97 & 28.2 & 40.8 & 8.9 & 31.7 & Dec-99 & 3 & 8 \\
\hline Sept-97 & 47.2 & 33.9 & 19.5 & 31.2 & Sep-00 & 2 & 7 \\
\hline Feb-98 & 31.4 & 22.9 & 14.8 & 24.9 & & & \\
\hline July-98 & 14.6 & 54.4 & 14.4 & 38.1 & & & \\
\hline Sept-98 & 49.8 & 52.5 & 45.4 & 39.0 & & & \\
\hline Feb-99 & 21.5 & 34.5 & 32.7 & 25.0 & & & \\
\hline & & & & & & & \\
\hline & & & & & & & \\
\hline
\end{tabular}

\section{Study of the habitat and occupancy rates}

\section{Oir watershed}

Flood episodes generally occur between December and February, and therefore do not affect the postemergence phase. For this reason, the impact of strong discharge on this life cycle stage was not studied at this site. Daily mean temperatures recorded in the Oir from 1986 to 1998 varied from $1{ }^{\circ} \mathrm{C}$ (winter '96-97') to $21^{\circ} \mathrm{C}$ (1991).

The habitat quality remained relatively stable from year to year throughout the period of the study. Globally speaking, this habitat quality is better for trout in the main river than in the affluents. The potentially limiting periods in the year are the lowflow periods in summer for all life stages, and winter flood periods for young fish.

The real occupancy rates observed throughout the period of study for the watershed as a whole are relatively low. It is clear that the population is in a recolonization period and has not yet reached a balance corresponding to the potential carrying capacity. Therefore, the potential biomass chosen for the compensation function was $30 \mathrm{~g} / \mathrm{m}^{2}$ of WUA (for adult stage) in low-flow periods (the lower limit of the range previously given for French streams); this poten- 
tial biomass corresponds to a total biomass of $142 \mathrm{~kg} / \mathrm{ha}$ which is consistent with biomasses observed in other watersheds in the region (Gouraud et al., 1997).

On a more local scale, displacement is simulated for all biomasses exceeding the maximum occupancy rate observed during the period of study in the most densely populated reach, i.e. $44 \mathrm{~g} / \mathrm{m}^{2}$ of WUA; this rate may be underestimated here, as the population level is undoubtedly lower than the point of equilibrium.

\section{The Neste d'Oueil}

The short period over which discharges were recorded was insufficient for an in-depth hydrological analysis. The impact of strong discharge on young life stages, apparently not a limiting factor at this site, will therefore not be examined. Daily temperatures varied from $1.3^{\circ} \mathrm{C}$ to $16.3^{\circ} \mathrm{C}$.

Occupancy rates found on the Neste d'Oueil are significantly higher. For the entire river, the rate observed in low-flow periods is relatively stable $-70 \mathrm{~g} / \mathrm{m}^{2}$ of WUA - during the 3 years of monitoring, and appears to give a good picture of the carrying capacity of the physical environment.

On a more local scale, the maximum occupancy rates observed vary widely from one measurement site to another (from 45 to $120 \mathrm{~g} / \mathrm{m}^{2}$ of WUA), but remain stable at each site over the years; this also appears to give a good picture of the carrying capacity of each of the 7 reaches. It is these reaches which determine the different sectors used for simulating displacement due to habitat limitation.

\section{The Roizonne}

The potential biomass of adult in the reach around which the population tends to balance itself is set at 65 $\mathrm{g} / \mathrm{m}^{2}$ of WUA (maximum of the range observed in French rivers), a value which appears to correspond to the mean observed biomass in the downstream reach, the most exposed to limitation due to low discharge (Capra et al., 2003). On a more local and instantaneous scale, displacement is simulated when the occupancy rate exceeds the maximum observed biomass in fishing inventories, or $90 \mathrm{gm}^{-2}$ of WUA (Capra et al., 2003).

To test our hypothesis that the post-emergence phase is particularly sensitive to hydrology, the value for the threshold discharge was set at $6.4 \mathrm{~m}^{3} \mathrm{~s}^{-1}$ (mean discharge + 2 standard deviations). In view of the preceding results for WUA as a function of discharge, $6.4 \mathrm{~m}^{3} \mathrm{~s}^{-1}$ indeed corresponds to a significant decrease in habitat availability for the $0+$ class. The total number of days (sum of days of the CUT curves established for March and May) on which discharge exceeds the threshold value of $6.4 \mathrm{~m}^{3} \mathrm{~s}^{-1}$ over this period ranges from 2 to 36 days. The threshold is exceeded almost every year after 1995 (with the exception of 1998). 


\section{Simulation results}

Restoration of the population after a climatic episode - Oir basin

The fry densities simulated from 1988 to 1998 are far higher than those observed (Figure 5a); however, the simulated densities correspond better to the stocks of breeder adults actually present in the watershed than do the observed densities. This difference between calculation and observation for fry might correspond to an underestimation of $0+$ during electrofishing due to the small size of these individuals. The simulated change trends are, however, quite consistent with those observed, except in 1994 and 1998.

The numbers of individuals in the $\geq 1+$ class are well represented (Figure $5 b$ ). The simulated numbers of $0+$
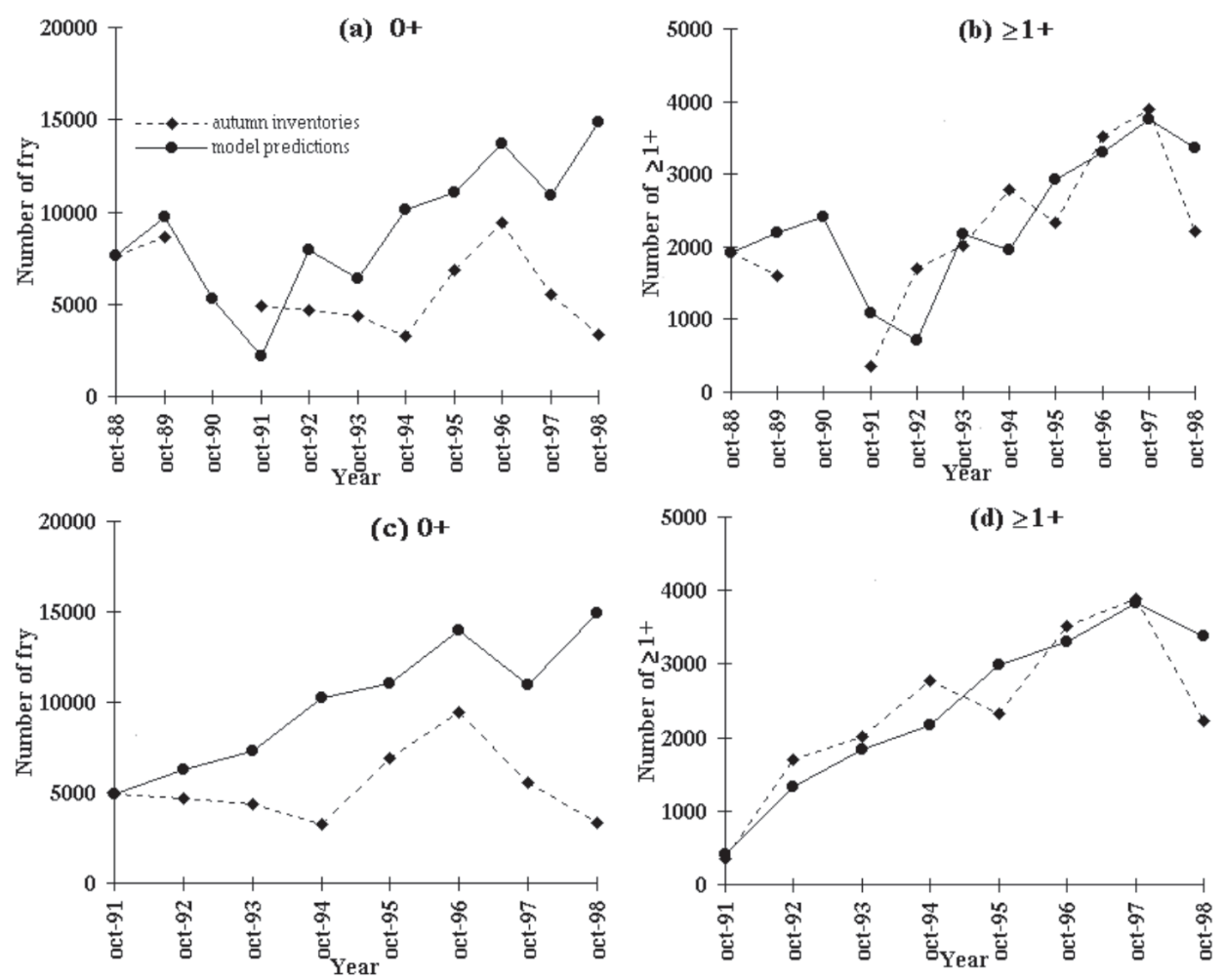

Fig. 5. - Oir site - model predictions in October from 1988 to 1998 compared to autumn inventories for fry (a) and " $\geq 1+$ " (b); and from 1992 to 1998 after the climatic incident in 1991 for fry (c) and " $\geq 1+$ " (d), from Gouraud et al. (2001) 
and $\geq 1+$ increase between 1988 and 1998 , though there is a drop in $0+$ in 1990, 1991 and 1997 due to the high summer temperatures. The extreme temperatures observed in 1991 also cause a drop in the $\geq 1+$ class. The decrease in the number of $0+$ individuals in 1991 results in a decline in the number of $\geq 1+$ adults in 1992. By a domino effect, this gives a drop in the number of recruits in 1993 and in the number of $\geq 1+$ in 1994.

The impact on $0+$ individuals of the summer thermal accidents in 1991 and 1997 is partially represented this time. It appears, however, that in 1991 the simulated impact on fry is too great, and on the $\geq 1+$ insufficient; this may explain the series of discrepancies then observed between simulations and observations up to 1994.

To test the ability of the model to simulate restoration of the population after an accident, we ran another simulation beginning in 1991 (after the thermal incident), taking as initial values the stocks observed in October 1991 (Figures 5c and 5d). The numbers of $0+$ and $\geq 1+$ increase regularly from 1991 to 1996 . In 1997, we find the drop due to the high summer temperatures which affects the $\geq 1+$ in 1998. These change trends for the $\geq 1+$ are very similar to those actually observed, except in 1995 when the decline in numbers is not simulated. The change in the number of $0+$ from 1994 to 1997 is well represented, but the model does not simulate the drop observed in 1998.
Regulation owing to carrying capacity conditions - Neste d'Oueil

The first simulation took as a hypothesis that there is no displacement or mortality when the carrying capacity is exceeded. The results obtained are very satisfactory in some reaches (such as Mayrègne downstream - Figure 6a). The biomasses are greatly overestimated, however, at others (such as Bourg - Figure 6b).

Supposing displacement in the event of fluctuations in the habitat, the biomass is limited by the carrying capacity in the summer at the sites where the biomass was previously overestimated, and the simulations are far closer to actual observations of biomass (Figure 6c).

In fact, in some sectors, the populations remain below the carrying capacity through the majority of the period of monitoring. No limitation due to the habitat is found. In other areas, the biomass is limited at least once a year between February and September in the simulation, bringing the estimations to the levels actually observed.

Dramatic decline in the population with strong flooding - Roizonne

The structure of the initial population (corresponding to the stocks observed in 1990) breaks down: the proportion of fry is very low, leading to a drop in numbers of $1+$ in 1991 and a decrease in the number of breeder adults in 1992. This, in turn triggers a drop in 0+ densities in 1993, lowering 

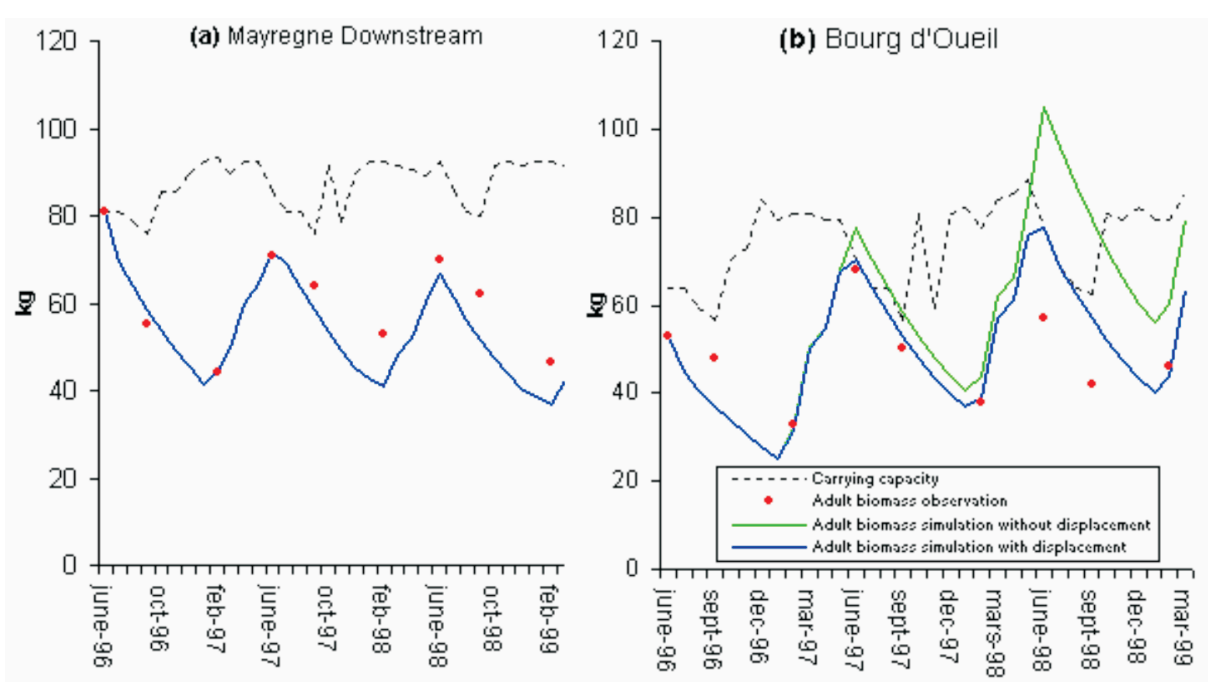

Fig. 6. - Neste d'Oueil - model predictions for adults compared to real inventories at Mayregne downstream (a) and Bourg d'Oueil (b) with no simulation of displacement; and at Bourg d'Oueil (c) with displacement simulated when biomass exceeds carrying capacity, from Gouraud et al. (2001)

the numbers of $1+$ in 1994 and of $>1+$ in 1995 (Figures 7).

In the upstream reach, without taking springtime floods into account, an increase in trout number is simulated globally from 1990 to 2000 for the three life stages $(0+, 1+$ and $>1+)$. The densities observed are far lower than those simulated.

Considering the flood discharge threshold of $6.4 \mathrm{~m}^{3} \mathrm{~s}^{-1}$, we simulate $50 \%$ mortality during the spring floods; the impact of the strong discharge on the fry population in 1994, 1995, 1996, 1999 and 2000 is partially represented, even though the numbers simulated remain higher than those estimated from inventories. Simulated mortality of $75 \%$ gives better agreement between observations and simulations, except for the 0+ between 1999 and 2000 .

Lastly we should note that no displacement of fish is simulated during the study period, given that no particularly severe drought resulted in habitat conditions more limiting than those of normal low-water conditions.

\section{DISCUSSION}

Platts and Nelson (1988), Stalnaker et al. (1996) and Bovee et al. (1998) have all underscored the benefits of studying habitat dynamics to understand or evaluate the re- 

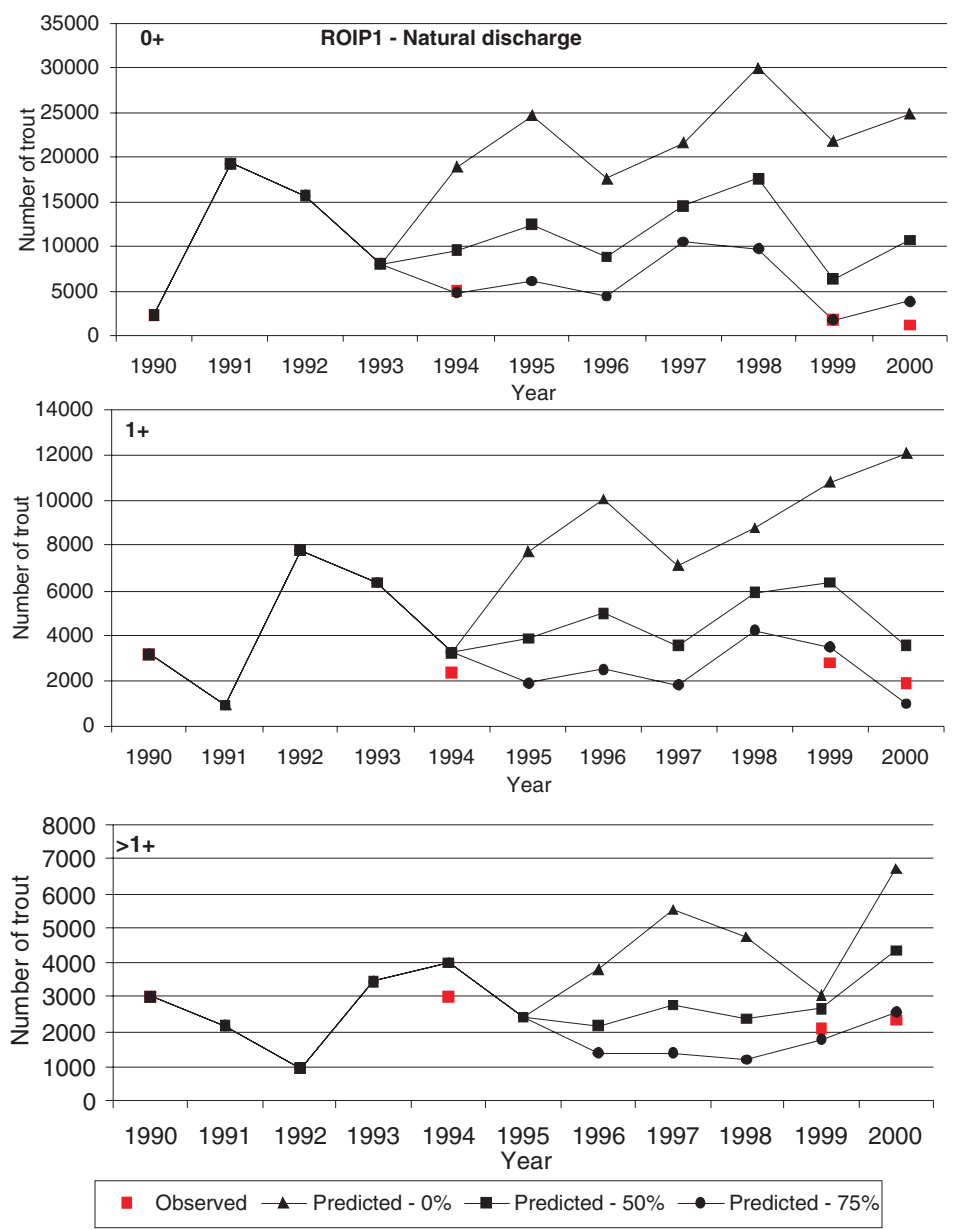

Fig. 7. - Results of MODYPOP simulations of trout numbers from 1990 through 2000 in reach 1. The initial input corresponds to the populations in 1990. Results are presented for each life stage. From Capra et al. 2003

sponse of a fish population to changes in discharge. Rieman and Myers (1997) have stressed the lack of sufficiently prolonged biological monitoring to provide an accurate analysis of demographic variations in salmonid populations over the long term.
The study presented here of three populations of trout with extremely different characteristics in terms of both their biological cycle and their evolution over time, has highlighted the role of the habitat in the overall dynamics of the population through three quite diverse phenomena: 
- the tendency of the population to return to a level compatible with the potential offered by the environment following a thermal incident,

- regulation of the population by the habitat in low-water periods,

- limitation of the population by strong spring floods.

\section{Time and space scale}

The space and time scales for these phenomena differ. On the Neste d'Oueil, trout displacement was simulated using a one-month time step, which allowed for a good reproduction of evolution in adult abundance through the year. In the Oir basin, on the other hand, a oneday scale was needed to take the thermal incident into account, as a monthly scale is insufficient when studying this type of very occasional event (Gouraud et al., 1998). Similarly, on the Roizonne, very sporadic but strong flooding has a major impact, particularly on young trout, which may not be seen on a onemonth time scale. The concept of Continuous Under Threshold (CUT) Curves (Capra, 1995) helps in refining the choice of time scale so as to better represent limiting periods, particularly in the post-emergence phase. This approach might also enable better identification of critical phases in the reproduction, subgravel and post-emergence phases.

The choice of spatial area for the population study is problematic; it must be large enough to be able to take into account all movement essential to the biological cycle of the population, and may differ from one site to another. To pinpoint the impact of the role of habitat on fish population dynamics, we must study a closed population, and therefore take into account exchanges between the main stream and its affluents. These exchanges are particularly important for the Oir basin, where the tributaries serve as nursery affluents (Gouraud et al., 1997, 1998, 1999). On the Neste d'Oueil, it was also necessary to allow for exchanges with apparently not very productive affluents to understand the population dynamics; furthermore, releases of hatchery fry had to be integrated.

On a smaller scale, accounting for displacement due to a momentary degradation of the environment raises the problem of the spatial unit, which depends on the way the fish exploit the habitat (Dajoz, 1982). Roussel (1998) has pointed up a functional unity in the habitat, consisting in a pool-riffle sequence, and Baran (1995) has shown the influence of the proportion of riffles in the reach on adult abundance in pools (Baran, 1995). The spatial unit chosen is therefore highly dependent on the environmental characteristics and on the biological needs of fish. An analysis of spatial and temporal variability in the occupancy rates in the Neste d'Oueil has shown that the reaches chosen represented ecological entities which satisfied the concept of spatial unit as defined in the 
model. The unit chosen for the model must, in any event, be large enough for the simulated displacement to be representative of accidental movement due to degradation in environmental conditions, resulting in significant mortality.

\section{Stabilization of populations and balance}

The concept of population stability is at the heart of most theoretical studies of population dynamics (Elliott, 1994). This notion of self-regulation is often described as a phenomenon of density-dependant mortality in early life stages. Regulation can also occur in the adult stage in some trout populations (Elliott \& Hurley, 1998). The model hypotheses concerning this concept are, first, that between two "disruptive" episodes, the population tends to return to a state of balance, and second, that this balance will depend on the potential offered by the environment. Monitoring of the populations of the Oir basin and the Neste d'Oueil has confirmed these hypotheses.

This self-regulation is simulated in the model by means of a compensation phenomenon in the first months of life and by phenomena of displacement.

In the Oir watershed, the continuous increase in biomass and the rate of occupancy of the available habitat - with no change in the habitat itself show clearly that the abundances are lower than the environmental poten- tial. Inventories conducted since 1991 have made it possible to monitor the progressive recolonization of the environment. The phenomenon of density-dependent mortality introduced in the model by means of the compensation function for survival in the first months of life enables a good representation of this rebalancing of the population toward a level compatible with the available habitat.

On the Neste d'Oueil, on the other hand, the river appears close to saturation, and abundance, which remains very stable from one year to the next, tends to be balanced around the local carrying capacity. The displacement phenomena integrated in the model simulate this regulation in periods of extremely low summer flow, whereas considering phenomena of growth and survival alone would give a serious over-saturation of the environment in some summers, although this was never observed.

On the upstream part of the Roizonne, however, the population appears to be regulated more by flood episodes than by summer lowwater conditions. Taking only the summer limitation into account did not give simulations of the low numbers of fish that were actually observed. The phenomena of regulation introduced in the model to balance the population at a level compatible with the potential of the environment in these low-water periods (densitydependent mortality and displacement in the event of overcrowding) should tend to bring the predicted population to a level proportional to 
the WUA in low-water periods. However, biomass, both simulated and observed, remained lower than the potential for the environment: the preponderant reason would appear to be strong discharge.

\section{Role of environmental parameters}

\section{Temperature}

Temperature has a direct impact on trout survival. While experiments in controlled environments allow for highlighting this phenomenon (Spaas, 1960; Bishai, 1960; Frost \& Brown, 1967; Gardside, 1973; Elliott, 1981), they do not reflect the reality of thermal conditions as actually experienced by the fish. However, thermal preference curves as given by Bovee (1982) have the advantage of "illustrating" fish behavior in a natural environment at each stage of development, and quantifying their needs in terms of thermal conditions. Applying the model to the Oir watershed showed that the impact of temperature on survival of individuals can be roughly approximated using these preference curves. The observed importance of this parameter in the case of high summer temperatures, however, and the complexity of its effects on fish biology (problem such as acclimation (Elliott, 1981) and linkage with other parameters like oxygen (Raleigh, 1986)) will ultimately require more in-depth analysis if we are to understand its real impact.

Moreover, though the effects were not observed here, very low tempera- tures may also limit migration for the purpose of reproduction.

\section{Habitat conditions}

Habitat conditions during the embryo-larval stage may also play a significant role in the population dynamics. During incubation, strong discharge may displace the upper layers of the substrate where trout eggs are buried (10-15 cm deep according to DeVries, 1997). However, Lapointe et al. (2000) have shown in other types of rivers that the substrate around the eggs was disturbed only by very strong floods ( hundred-year floods). This phenomenon was not observed at the sites studied here. On the other hand, the drop in $0_{+}$ numbers not simulated by the model in the Oir basin in 1998 indicates an accidental calamity for the sub-gravel stage which was probably due to an oxygen deficit, perhaps caused by clogging up of the spawning habitat by intensive agriculture-related activity (Gouraud, 1999).

Strong discharge after emergence plays a fundamental role in structuring trout populations. The results presented here of the study of fish population dynamics on the Roizonne confirm those of Cattanéo et al. (2002) in their study of 37 trout-bearing streams with natural discharge.

Episodes of high discharge may also affect the survival of juvenile or adult trout. Jowett \& Richardson (1989) show that trout biomass in several New Zealand streams drops significantly after a flood episode (by 
between $26 \%$ and $57 \%$ ). Allen (1951) and Hoopes (1975) tell of similar variations. In their Habitat Quality Index (HQI) model, Binns \& Eiserman (1979) also indicate that very high annual fluctuations in discharge are detrimental to trout biomass.

Finally, low-flow periods may be limiting episodes for adults (Souchon et al., 1989), as was shown to be the case on the Neste d'Oueil. The displacement simulated by Modypop when stocks exceed carrying capacity revealed this type of limitation on this stream. It is difficult, however, to determine real carrying capacity. The variability in occupancy rates between sites and between sectors on any given river points up the importance of other environmental parameters such as slope, potential for shelter, variety in flow characteristics, agricultural activity in the watershed, on the concept of carrying capacity. Comparisons between various sites and the determination of certain common characteristics for each type of habitat should make it possible to understand this variability better.

\section{CONCLUSION}

The study described here of three populations has highlighted the fundamental role of the temporal variability of environmental parameters (particularly temperature, discharge and WUA) in structuring trout populations. The objective now is to simulate trends in a population following a change in the water management mode, to provide decision-makers with elements that can inform their choices.

To this end, a study is now under way on eight sites in France to examine changes in trout populations in bypassed sections downstream of hydropower plants following a significant increase in the minimum instream flow.

\section{REFERENCES}

Allen K.R. 1951. The Horokiwi stream: a study of a trout population. New Zealand Marine Department Fisheries Bulletin, 10: 1-238.

Bagliniere J.L. and G. Maisse 1991. La truite biologie et écologie. INRA Editions, Paris.

Baran P. 1995. Analyse de la variabilité des abondances de truites communes (Salmo trutta L.) dans les Pyrénées centrales françaises. Thesis. Ecole Nationale Supérieure Agronomique, Toulouse, France.

Binns N.A. and F.M. Eiserman 1979. Quantification of fluvial trout habitat in Wyoming. Transactions of the American Fisheries Society., 108(3): 215228.

Bishai H.M. 1960. Upper lethal temperatures for larval salmonids. J. Conseil perm. Int. Explor. Mer. 25: 129-133.

Bovee K.D. 1978. Probability of use criteria for the family Salmonidae. FWS/ OBS 78/07, U.S. Fish and Wildlife Service, Fort Collins, Colorado USA.

Bovee K.D. 1982. A guide to stream habitat analysis using the instream flow incremental methodology. Instream Flow Information Paper No. 12. FWS/ OBS-82/26. U.S Fish and Wildlife Service, Fort Collins, Colorado USA. 
Bovee K.D., B.L. Lamb, J.M. Bartholow, C.B Stalnaker, J. Taylor and J. Henriksen 1998. Stream habitat analysis using the instream flow incremental methodology. USGS/BRD-1998-0004, U.S. Geological Survey, Fort Collins, Colorado USA.

Capra, H. 1998. Histoire d'habitat. Relations quantitatives entre la dynamique des populations de truite commune et la variabilité temporelle de l'habitat. Vers une meilleure connaissance des habitats structurants. 1998/2, EDFDTG/Cemagref.

Capra H. and Y. Souchon 2000. Influence du débit sur la dynamique d'une population de truite en aval d'un ouvrage hydroélectrique. Résultats des pêches effectuées en 2000 sur la Roizonne. EDF-DTG/Cemagref.

Capra H., P. Breil and Y. Souchon 1995. A new tool to interpret magnitude and duration of fish habitat variations. $R e$ gulated Rivers: Research and Management 10: 281-289.

Capra H., C. Sabaton, V. Gouraud, Y. Souchon, and P. Lim 2003. A Population Dynamics model and habitat simulation as a tool to predict brown trout demography in natural and bypassed stream reaches. Rivers Research and Applications, 19: 551-568.

Cattanéo F., N. Lamouroux, P. Breil and H. Capra 2002. The influence of hydrological and biotoc processes on brown trout (Salmo trutta) population dynamics. Canadian Journal of Fisheries and Aquatic Sciences 59: 12-22.

Cheslak E.F. and A.S. Jacobson 1990. Integrating the Instream Flow Incremental Methodology with a Population Response Model. Rivers 1: 264-288.

Dajoz R. 1982. Précis d'écologie. Dunod Université, Paris.

Delacoste M., P. Baran, S. Lek and J.M. Lascaux 1995. Classification et clé de détermination des faciès d'écoulement en rivière de montagne. Bulletin Fran- çais de la Pêche et de la Pisciculture, 337/338/339: 149-156.

DeVries P. 1997. Riverine salmonid egg burial depths: review of published data and implications for scour studies. $\mathrm{Ca}$ nadian Journal of Fisheries and Aquatic Sciences 54: 1685-1698.

Elliott J.M. 1981. Some aspects of thermal stress on freshwater teleosts. Pages 209-245 in A.D. Pickering (ed.), Stress and Fish. London: Academic Press.

Elliott J.M. 1994. Quantitative ecology and the brown trout, Oxford: Oxford University Press.

Elliott J.M. and M.A. Hurley 1998. Population regulation, but not juvenile, resident trout (Salmo trutta) in a Lake District stream. Journal of Animal Ecology, 67: 280-286.

Frost W.E. and M.E. Brown 1967. The trout. St. James Place, London: Collins.

Gardside, 1973. as cited in CRISP D.T., 1996. Environmental requirements of common riverine European salmonid fish species in fresh water with particular reference to physical and chemical aspects. Hydrobiologia, 323: 201-221.

Gouraud V., J.L. Bagliniere, D. Ombredane, C. Sabaton and F. Marchand 1997. Caractéristiques biologiques de la population de truites (Salmo trutta L.) de la rivière Oir (Manche, BasseNormandie) en 1996-97. 1 - La population en place. Rapp. Contrat INRA/ EDF-DER, Lab. Ecol. Aquat., INRA Rennes.

Gouraud V., J.L. Baglinière, C. Sabaton and D. Ombredane 1998. Application d'un modèle de dynamique de population de truite commune (Salmo trutta) sur un Bassin de Basse Normandie Calage des fonctions biologiques et premières simulations. Bulletin Français de la Pêche et de la Pisciculture, 350-351: 675-691.

Gouraud V. 1999. Etude de la dynamique de populations de truite commune 
(Salmo trutta L.) à l'aide d'un modèle déterministe. Thesis. ENGREF, Paris.

Gouraud V, P. Baran, P. Lim and C. Sabaton 1999. Dynamics of a population of brown trout (Salmo trutta) and fluctuations in physical habitat conditions experiments on a stream in the Pyrenees; first results. Pages 126-142 In Cowx IG (ed.) Rivers Fisheries, Fishing News Books, Oxford: Blackwell Science.

Gouraud V., J.L. Baglinière, P. Baran, C. Sabaton, P. Lim and D. Ombredane 2001. Factors regulating brown trout populations in two French rivers: application of a dynamic population model. Regulated Rivers: Research and Management, 17: 557-569.

Hoopes R.L. 1975. Flooding as the result of hurricane Agnes, and its effect on a native brook trout population in an infertile stream in Central Pennsylvania. Transactions of the American Fisheries Society, 104: 96-99.

Jager H.I., D.L. De Angelis, M.J. Sale, W. Van Winkle, D.D. Schmoyer, M.J. Sabo, D.J Orth. and J.A. Lukas 1993. An individual-based model for smallmouth bass reproduction and youngof-the-year dynamics in streams. Rivers, 4: 91-113

Jowett I.G. and J. Richardson 1989. Effects of a severe flood on instream habitat and trout populations in seven New Zealand rivers. New Zealand Journal of Marine and Freshwater Research, 23: 11-17.

Kondolf G.M., E.W. Larsen and J.G. Williams 2000. Measuring and modeling the hydraulic environment for assessing instream flows. North American Journal of Fisheries Management, 20: 1016-1028.

Lamouroux N., H. Capra, M. Pouilly and Y. Souchon 1999. Fish habitat preferences in large streams of southern France. Freswater Biology, 42: 673687.
Lapointe M., B. Eaton, S. Driscoll and C. Latulippe 2000. Modelling the probability of salmonid egg pocket scour due to floods. Canadian Journal of Fisheries and Aquatic Sciences, 57: 11201130.

Latterell J.J., K.D. Fausch, C. Gowan and S.C. Riley 1998. Relationship of trout recruitment to snowmelt runoff flows and adult trout abundance in six Colorado Mountain streams. Rivers, 6: 240250.

Leslie P.H. 1945. The use of matrices in certain population mathematics. Biometrika, 33: 183-212.

Nehring R.B. and R.M. Anderson 1993. Determination of population-limiting critical salmonid habitats in Colorado streams using the physical habitat simulation system, River, 4: 1-19.

Platts W.S. and Nelson R.L. 1988. Fluctuations in trout populations and their implications for land-use evaluation. North American Journal of Fisheries Management, 8: 333-345.

Pollard P. and M. Huxham 1998. The European Water Framework Directive: a new era in the management of aquatic ecosystem health ? Aquatic Conservation: Marine and Freshwater Ecosystems, 8: 773-792.

Raleigh R.F., L.D. Zuckerman and P.C. Nelson 1986. Habitat Suitability Index models and Instream Flow Suitability curves: Brown trout, revised. U.S. Fish. Wild. Serv. Bio. Rep. 82: 10-124.

Resh V.H., A.V. Brown, A.P. Covich, M.E. Gurtz, H.W. Li, G.W. Minshall, S.R. Reice, A.L. Sheldon, J.B. Wallace and R.C. Wissmar 1988. The role of disturbance in stream ecology. Journal of North American Benthological Society, 7: 433-455.

Rieman B.E. and D.L. Myers 1997. Use of redd counts to detect trends in bull trout (Salvelinus confluentus) populations. Conservation Biology, 11: 10151018. 
Roussel J.M. 1998. Utilisation de l'espace par la truite commune (Salmo trutta L.) au cours du nycthémère. Un exemple du rôle fonctionnel de l'habitat en ruisseau. Thèse de Doctorat, Sciences de I'Environnement, ENSAR. Paris.

Sabaton C. 2002. Development and use of fish habitat and population dynamics models as management tools for hydropower plants: Overview of Electricité de France experience. Enviro Flows. 2002. Proceedings of the International Conference on Environmental Flows for River Systems, incorporating the $4^{\text {th }}$ International Ecohydraulics Symposium. Unpublished proceedings. Cap Town, March 2002.

Sabaton C., L. Siegler, V. Gouraud, J.L. Bagliniere and S, Manne 1998. Presentation and first applications of a dynamic population model for brown trout (Salmo trutta) - aid to river management. Fisheries Management and Ecology, 4: 425-438.

Souchon Y., F. Trocherie, E. Fragnoud and C. Lacombe 1989. Les modèles numériques des microhabitats des poissons: application et nouveaux développements. Revue des Sciences de l'Eau, 2: 807-830.
Souchon Y. and P. Keith 2002. Freshwater fish habitat: science, management and conservation in France. Aquatic Ecosystem Health and Management, 4: 401-412.

Souchon Y., P. Breil, H. Andriamahefa, M.B. Albert, H. Capra and N. Lamouroux 2002. Couplage physique-biologie dans les cours d'eau: vers une hydroécologie plus quantitative. Natures Sciences et Sociétés, 10: 26-41.

Spaas J.T. 1960. Contribution to the comparative physiology and genetics of the European Salmonidae. III. Temperature resistance at different ages. $\mathrm{Hy}$ drobiologia, 15: 78-88.

Stalnaker C.B, K.D. Bovee and T.J. Waddle 1996. Importance of the temporal aspects of habitat hydraulics to fish population studies. Regulated Rivers: Research and Management, 12: 145-153.

Williamson S.C., J.M. Bartholow and C.B Stalnaker 1993. Conceptual model for quantifying pre-smolt production from flow-dependent physical habitat and water temperature. Regulated Rivers: Research and Management, 8: 15-28. 